\title{
Distribution and demographic parameters of the Peregrine falcon Falco peregrinus L., 1756 in Gipuzkoa.
}

\section{Distribución y parámetros demográficos del halcón peregrino Falco peregrinus L., 1756 en Gipuzkoa.}

Mikel Olano ${ }^{1,2}$, Fermin Ansorregi ${ }^{2}$, Tomas Aierbe ${ }^{1,2}$, Rober Hurtado ${ }^{2}$, Javier Vázquez ${ }^{2}$, Jon Ugarte ${ }^{2}$, Haritz Beñaran ${ }^{2}$, Aitor Galdós ${ }^{2}$, Juan Arizaga ${ }^{1 *}$

$\xi^{*}$

\begin{abstract}
1 Department of Ornithology, Aranzadi Sciences Society

Zorroagagaina 11, 20014 Donostia-S. Sebastián, Spain

2 Gipuzkoa Administration

Plza. Gipuzkoa s/n, 2004 Donostia-S. Sebastián, Spain

*Corresponding author: jarizaga@aranzadi.eus
\end{abstract}

Gathering information on the distribution and population size is crucial in order to develop precise conservation actions, especially in threatened species or those of special concern. The aim of the present article is to update the population status and the breeding parameters of the Peregrine falcon Fa/co peregrinus L., 1756 in Gipuzkoa. We also used data obtained from previous studies in order to estimate population trends in the region (2000-2017). In 2017, 35 territories were detected. During the period from 1990 to 2000, the mean breeding population size increased 79.4\%, but from 2000 to 2017, the increase was just 3.2\%. However, the latter increase was not statistically significant. Therefore, it can be concluded that the population has remained stable for the last two decades. The Peregrine falcon is well distributed in Gipuzkoa, except for the central-eastern part of the region. The nests were found on inland cliffs (48.6\%), marine cliffs (25.7\%), quarries (22.9\%) and buildings (2.9\%). The breeding parameters in 2017 (productivity: $1.72 \pm 1.36$ offspring/breeding pair, $n=35$; flight rate: $2.50 \pm 0.83$ offspring/nest, $n=24$; breeding 
success, 92\%) did not differ significantly from previous years within the region. In conclusion, the peregrine falcon population in Gipuzkoa has remained constant during the last two decades (from 2000 to 2010, and up to 2017), with one of the highest breeding densities in Spain. Breeding parameters are also high and, overall, the conservation status of the population is apparently good in Gipuzkoa.

Key words: Animal conservation, population dynamics, raptors.

\section{Laburpena}

Banaketaren eta populazioen tamainen datuen bilketa oinarrizkoa da kontserbazio egitasmo zehatzak garatzeko, bereziki espezie mehatxatuak direnean edo kontserbaziorako interesgarriak. Artikulu honen xedea Gipuzkoan, Belatz handiaren (Falco peregrinus L., 1756) populazioaren datuak eguneratzea da. 2017an, guztira 35 lurralde antzeman ziren. 1990-2000 hamarkadan, populazioa, batez beste \%79,4 hazi da. 2000-2017 epean, berriz, hazkundea \%3,2koa izan da. Beraz, populazioa egonkor mantendu da azken bi hamarkadetan.

Belatz handia ondo banaturik dago Gipuzkoan, lurraldearen erdi-mendebaldean izan ezik. Euskarriari dagokionez, kabiak barne aldeko harkaitzetan (\%48,6), zein itsaslabarretan $(\% 25,7)$ edo harrobietan $(\% 22,9)$ edo eraikuntzetan (\%2,9) aurkitzen ditugu. 2017an inkubazioa 26 lurraldetan erregistratu zen (\%74); horietatik 24k gutxienez kume bat ekoiztu zuten. 2017an ugalketa parametroak (produktibitatea: 1,72 $\pm 1,36$ kume/lurraldeko, $n=35$; hegatze-tasa: 2,50 0,83 kume/lurraldeko, $n=24$; ugaltze arrakasta, \%92) ez dute aldaketa handirik izan. Ondorioz, Belatz handiaren populazioak Gipuzkoan egonkor eutsi dio azken bi hamarkadetan (2000ko hamarkadan eta 2010eko hamarkadan, 2017ra arte), eta Penintsulako dentsitate handienekoa da. Ugalketa parametroek adierazten dutenez, lurraldean oro har, populazioak kontserbazio egoera ona du.

Gako hitzak: Animalien kontserbazioa, populazioen dinamika, harrapakariak.

\section{Resumen}

La recopilación de datos sobre la distribución y tamaño poblacional es algo básico para desarrollar acciones de conservación precisas, especialmente en especies amenazadas o de interés para la conservación. El objetivo de este artículo es actualizar los datos sobre la población de halcón peregrino Falco peregrinus L., 1756 en Gipuzkoa. En 2017, se detectaron un total de 35 territorios. De la década de 1990 a la de 2000, en promedio la población se incrementó un 79,4\%, mientras que de 2000 a 2017 el incremento fue del $3,2 \%$. En consecuencia, la población ha permanecido estable durante las últimas dos décadas. El halcón peregrino se distribuye bien en Gipuzkoa, excepto en la zona centro-occidental de la región. En cuanto a sustrato, hallamos nidos tanto en cantiles interiores $(48,6 \%)$ como costeros (25,7\%), además de canteras (22,9\%) y edificios (2,9\%). En 2017 se registró incubación en 26 territorios (74\%); entre éstos, 24 produjeron al menos un 
pollo. Los parámetros reproductores en 2017 (productividad: 1,72 \pm 1,36 pollos/territorio, $n=35$; tasa de vuelo: $2,50 \pm 0,83$ pollos/territorio, $n=24$; éxito reproductor, $92 \%$ ) no varió significativamente. En conclusión, la población de halcón peregrino en Gipuzkoa ha permanecido estable durante las últimas dos décadas (décadas de 2000 y 2010, hasta 2017), con una de las densidades más elevadas de España. Los parámetros reproductores sugieren, en conjunto, que la población goza de un buen estado de conservación en la región.

Palabras clave: Conservación animal, dinámica de poblaciones, rapaces.

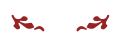

\section{Introduction}

Gathering information on the distribution and population size is crucial in order to develop precise conservation actions, especially in species of concern (Newton, 1998). Notably, one of the main,basic conservation tasks all around the world deals with the implementation of long-term population monitoring programs (Devictor et al., 2010, Dickinson et al., 2012, Jiguet et al., 2012).

The Peregrine falcon Falco peregrinus L., 1756 is a well distributed raptor worldwide (White et al., 2013). Globally evaluated as of Least Concern (BirdLife International, 2017), in Europe the species was considered to have an unfavorable conservation status (SPEC 3 category: species not only distributed in Europe, but with conservation problems in Europe) (Tucker \& Heath, 2004), though more recently its European populations have shown to be increasing (Staneva \& Burfield, 2017).

The population size in Spain is estimated at 2,462-2,804 pairs (Moral \& Molina, 2009). The conservation status of the species is considered unfavorable, because it is in decline in several regions and the entire population is $<10,000$ pairs (Moral \& Molina, 2009). Illegal hunting, and collisions and electrocutions with power lines are amongst the most important causes of the threat (Zuberogoitia et al., 2002). In the Basque Country, the species has a population size of ca. 100 pairs (2008 census), of which about 30 pairs breed in Gipuzkoa (Moral \& Molina, 2009).

The last detailed work on the distribution and main demographic parameters of the Peregrine falcon in Gipuzkoa refers to 2008 (Moral \& Molina, 2009). At the time, Gipuzkoa hosted an apparently healthy population (28 territories), with one of the greatest breeding densities documented in Spain (1.2 pair/100 km²) (Moral \& Molina, 2009). Productivity was not assessed for 2008 but for the period 2003-2005 (Álvarez et al., 2005), and was also relatively high as compared to other zones of Spain (1.68 chicks/breeding pair; the mean for Spain is estimated at 1.42) (Moral \& Molina, 
2009). Direct persecution (Arizaga \& Laso, 2015) and the possible increasing pressure on nest places (due to the growing popularity of climbing and wildlife photography) are two conservation problems with unknown effects on the Peregrine falcon population in Gipuzkoa.

The aim of the present article is to update the distribution and demographic parameters of the Peregrine falcon in Gipuzkoa. The type of substrate used to place the nests was also characterized.

\section{Material and methods}

\section{Study area and data collection}

This study was carried out in the province of Gipuzkoa (North of Spain). Gipuzkoa is a small, very mountainous area of almost $2,000 \mathrm{~km}^{2}$. The highest mountain reaches $1551 \mathrm{~m}$ above sea level. Situated in the southeastern part of the Bay of Biscay, between the western Pyrenees and the sea, its climate has a mean annual temperature of $14^{\circ} \mathrm{C}$ and the mean annual precipitation is ca. 1,400 mm.

The census protocol consisted of sampling by direct observation all those places which might potentially host a breeding pair (i.e., a territory), in accordance with del Moral \& Molina (2009). As "potential territory" we considered all those places with any type of rocky walls, including inland mountains, marine cliffs, quarries, as well as buildings, where the species was found previously or which potentially might host a breeding pair.

Each potential territory was visited at least three times during the breeding season from 15 February to 30 June 2017. From 15 Feb. to 15 Mar. we identified occupied territories by observing courtship and breeding display. From 15 Mar. to 14 Apr. we determined those breeding pairs that were incubating. From 15 Apr. up to 30 Jun. we quantified the number of nestlings (Zuberogoitia et al., 2002). The visits were made during a period of four hours after dawn and during the last four hours before dusk, avoiding the mid-day period.

We considered a zone to be a territory either by finding evidence of the presence of a territorial bird or pair (i.e., probable breeding; pair observed in a suitable nesting habitat in breeding season, agitated territorial behavior -calls, etc.-, bird or pair seen at the same site on two or more different days a week or further apart, courtship, visits to a probable nest site, nest building) or directly by locating a pair incubating or with chicks (i.e., confirmed breeding). Evidence of possible breeding (i.e., bird seen once in breeding season in a possible nesting habitat) was excluded as active territories. 
Apart from the data collected in 2017, we also used data from previous censuses, either published (up to 2008) (Zuberogoitia et al., 2002, Álvarez et al., 2005, Moral \& Molina, 2009) or unpublished (years: 2010, 2011, 2012; source: own data) in order to estimate population trends within the region. Unpublished data were obtained with the same protocol used in 2017 (see above for further details).

\section{Data analyses}

The altitude of the territories was determined with GIS (hypsometric map for the Basque Country; geo.euskadi.eus). GIS analyses were done using QGIS (QGIS Development Team, 2009).

The software TRIM (Pannekoek \& Van Strien, 2005) was used to estimate population trends using the data censuses (2010-2017).

Regarding breeding parameters, we calculated a total of three variables (Steenhof \& Newton, 2007): productivity (number of fledged offspring divided by the number of confirmed territories), flight rate (number of fledged offspring divided by the number of nests where at least one offspring was observed to fledge), breeding success (percentage of nests from which at least one chick fledged in relation to all nests where there was incubation). We provided mean and standard deviation (SD) for all the breeding parameters reported. We used a K-W test in order to compare productivity between habitats (marine cliffs, inland cliffs, quarries) in 2017. In this case, we used a non-parametric approach due to low sample sizes $(n<10)$ in two of the habitats compared (marine cliffs, quarries). Moreover, we used an ANOVA to compare whether the productivity and flight rate in 2017 differed from other previous years during the decade of 2010 . For breeding success, a chi-square test was used for the same comparison.

Statistical analyses were carried out using the R programme (R Core Team, 2014). The significance level considered in all the statistical analysis was 0.05 .

\section{Results}

\section{Population distribution}

In 2017, the species was relatively well distributed across the region, except within the central-eastern part of Gipuzkoa (Fig. 1). $46 \%$ of the nests were situated within an altitude of under $200 \mathrm{~m}$ a. s. I. (Fig. 2).

The nests were found to be placed in inland cliffs ( $n=17 ; 48.6 \%)$, marine cliffs ( $n=9 ; 25.7 \%)$, quarries $(n=8 ; 22.9 \%)$ or buildings ( $n=1 ; 2.9 \%)$. 


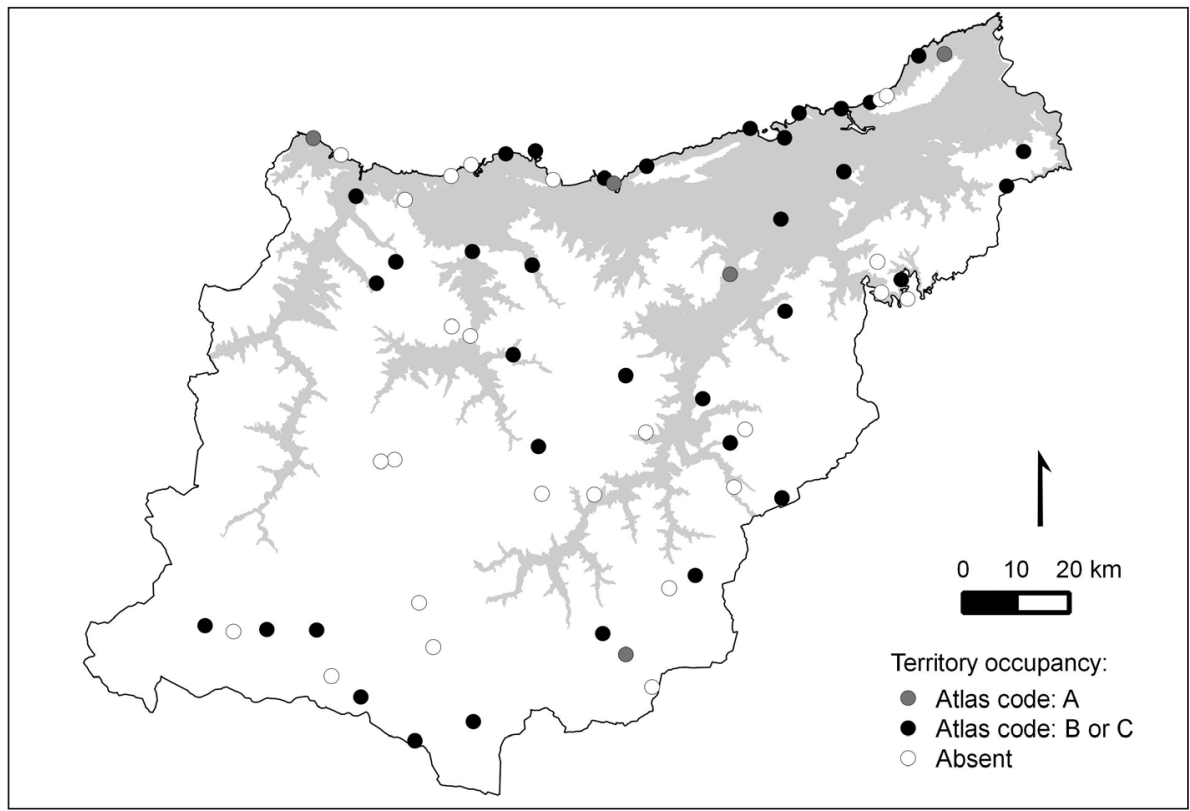

Fig. 1.- Possible, probable or confirmed (black/grey dots, $n=40$ ) or surveyed but non-detected (open dots) Peregrine falcon territories in Gipuzkoa, in 2017. Shadow polygons show areas below $200 \mathrm{~m}$ above sea level.

Fig. 1.- Territorios de cría posible, probable o segura (puntos negros o grises, $n=40$ ) y negativos (puntos en blanco) de halcón peregrino en Gipuzkoa, en 2017. El área en gris indica una altitud por debajo de $200 \mathrm{~m}$ sobre el nivel del mar.

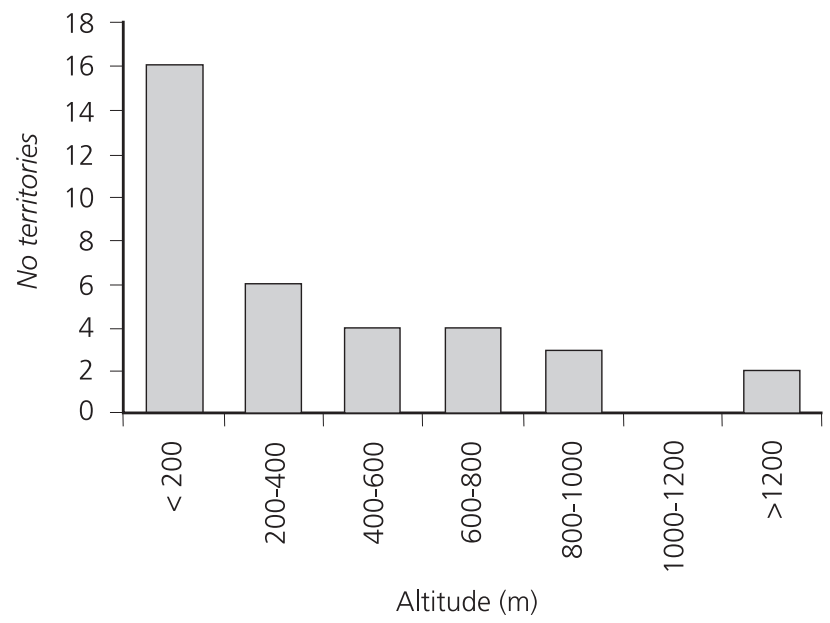

Fig. 2.- Altitudinal distribution of the Peregrine falcon territories in Gipuzkoa $(n=35)$, in 2017.

Fig. 2.- Distribución altitudinal de los territorios de halcón peregrino en Gipuzkoa ( $n=35)$, en 2017. 


\section{Census results}

Overall, during the census conducted in 2017, we visited 65 potential territory sites of which 40 were occupied. The mean time spent per visit was $68 \mathrm{~min}$ (SD= $36 \mathrm{~min}$; $n=360$ visits; total: 412.88 h). Of these occupied territories, 35 (87.5\%) were considered to be true territories (probable breeding, $n=9$; confirmed, $n=26$ ) (Fig. 1). In the five remaining sites we found no more than a single bird seen just once throughout the entire breeding period.

\section{Population trend}

Since 2010, the population of this species has been stable within the region (TRIM results: Wald test for the significance of the slope for a linear-trend model, $P=0.072$; (Fig. 3), ranging between 28 and 35 territories. However, the trend for the last three decades shows another pattern (Fig. 4): during the decade from 1990 to 2000, the mean population size increased 79.4\%, but during the decade from 2000 to 2010 , the increase was just 3.2\%. However, the latter increase was not statistically significant. Therefore, it can be concluded that the population has remained stable for the last two decades (i.e. the decade from 2000 to 2010, and up to 2017).

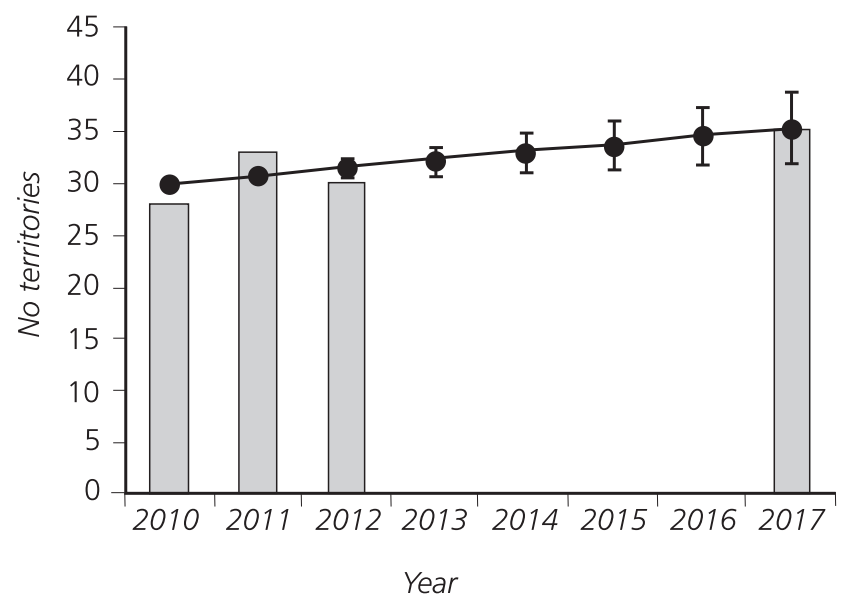

Fig. 3.- Number of territories of Peregrine falcon in Gipuzkoa during the period 2010-2017. Bars show observed territories; dots $( \pm \mathrm{SE})$ and line show the number of expected territories according to a model assuming a linear population increase, which was non-significant $(P>0.05)$.

Fig. 3.- Número de territorios de halcón peregrino en Gipuzkoa, durante el periodo 2010-2017. Las barras indican los valores observados; los puntos $\left({ }_{ \pm} \mathrm{SE}\right)$ muestran el valor esperado según un modelo que asume una tendencia lineal, que resultó ser no significativa $(P>0,05)$. 


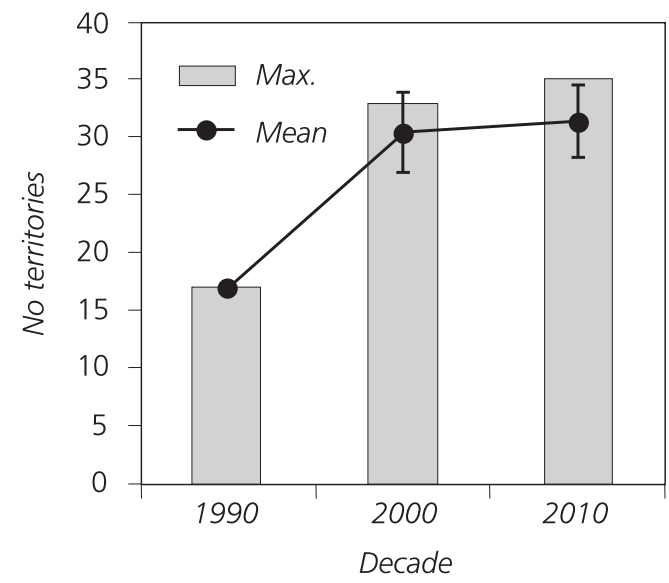

Fig. 4.- Maximum (bars) and mean $( \pm$ SD) number of territories of Peregrine falcon detected in Gipuzkoa during the 1990 ( $n=1$ census), 2000 ( $n=5$ census) and 2010 ( $n=4$ census) decades.

Fig. 4.- Número máximo (barras) y promedio $( \pm S D)$ de territorios de halcón peregrino en Gipuzkoa, durante las décadas de 1990 ( $n=1$ censo), 2000 ( $n=5$ censos) y 2010 ( $n=4$ censos).

\section{Breeding parameters}

Of the 35 territories observed in 2017, we detected incubation or offspring in 26 of them (74\%). Of these 26 nests, 24 produced at least one offspring (thus the breeding success was $92 \%$ ). The failure of two of the nests was caused by human disturbances (one of the nests failed because of clearing work and in the other one because a hiking path passed close to it). The mean flight rate was 2.5 offspring (SD $=0.8$ offspring; range: $1-4$ offspring, $n=24$ nests); and the mean productivity was 1.7 offspring (SD = 1.4 offspring, range: 0-4 offspring, $n=35$ territories).

Territories situated on marine cliffs tended to have a higher productivity $(2.6 \pm 1.0$ offspring) than those on inland cliffs (1.4 \pm 1.4 offspring) or quarries $(1.2 \pm 1.4)$, but the differences were non-significant ( $K-W$ test: $H=4.235, P=0.120$ ).

The breeding parameters in 2017 did not differ significantly in relation to other breeding years $(2010,2011,2012,2016)$ (Table 1).

\section{Discussion}

The population size of the Peregrine falcon in Gipuzkoa peaked in 2017 (35 pairs), a value which has remained constant since the beginning of the 2000s. Our results, therefore, show a stable population in Gipuzkoa during a period of ca. 20 years, coinciding with what has been observed in Bizkaia, a neighbouring region (Zuberogoitia et al., 2009). Theoretically, such stability may be due to the good demographic 


\begin{tabular}{|cccc|}
\hline Year & $\begin{array}{c}\text { Productivity } \\
\text { (offspring/nest) }\end{array}$ & $\begin{array}{c}\text { Flight rate } \\
\text { (offspring/nest) }\end{array}$ & $\begin{array}{c}\text { Br. Success } \\
(\%)\end{array}$ \\
\hline 2010 & $\begin{array}{c}1.64 \pm 1.22 \\
n=25\end{array}$ & $\begin{array}{c}2.28 \pm 0.75 \\
n=18\end{array}$ & 90 \\
\hline 2011 & $\begin{array}{c}1.32 \pm 1.32 \\
n=31\end{array}$ & $\begin{array}{c}2.28 \pm 0.90 \\
n=18\end{array}$ & 82 \\
\hline 2012 & $\begin{array}{c}1.20 \pm 1.28 \\
n=31\end{array}$ & $\begin{array}{c}2.30 \pm 0.70 \\
n=16\end{array}$ & 76 \\
\hline 2016 & $\begin{array}{c}1.26 \pm 1.18 \\
n=23\end{array}$ & $\begin{array}{c}2.07 \pm 0.73 \\
n=14\end{array}$ & 92 \\
\hline Statistics & $\begin{array}{c}2.72 \pm 1.36 \\
n=35\end{array}$ & $\begin{array}{c}n=24 \\
\mathrm{~F}_{4,140}=1.012\end{array}$ & $\begin{array}{c}\mathrm{F}_{4,85}=0.674 \\
\chi^{2}=3.44\end{array}$ \\
\hline -value & $P=0.404$ & $P=0.612$ & $P=0.511$ \\
\hline
\end{tabular}

Table 1.- Peregrine falcon breeding parameters (productivity, flight rate, breeding success) in Gipuzkoa during the decade of 2010.

Tabla 1.- Parámetros reproductores (productividad, tasa de vuelo y éxito reproductor) del halcón peregrino en la provincia de Gipuzkoa en la década de 2010.

performance of the Peregrine falcon population in Gipuzkoa (either in terms of productivity or survival), but also due to a high immigration rate, which would hence mask an unfavourable scenario in Gipuzkoa (Newton, 1998). The population in Bizkaia, showed demographic parameters (such as a high proportion of adults, high adult survival rates, high dispersal distances, small turnover rates, high fidelity to the territory and high recruitment age), that indicated good health levels (Zuberogoitia et al., 2009). With a mean of 1.5 offspring /pair (2.6 offspring /pair for those territories found on marine cliffs), the productivity shown for Gipuzkoa came within what is considered to be normal or even in the upper range for the species (Rizzolli et al., 2005), also in Spain (Moral \& Molina, 2009). The survival of fledglings as well as of adults is, however, an unresolved question in Gipuzkoa. On average, illegal hunting causes several deaths a year, of which some would belong to the local adult resident population. Thus, during a period of eight years (2006-2013), 13 Peregrine falcons were shot in Gipuzkoa (Arizaga \& Laso, 2015). Furthermore, only in 2017, at least three more adults were killed (source: Gipuzkoa forest ranger team). Demographic models will be necessary to determine to whether this mortality is too high to maintain a viable Peregrine falcon population in Gipuzkoa, since adult survival is critical for the demography of this species (Wootton \& Bell, 1992). 
The slightly higher productivity along the coast as compared to inland cliffs or artificial substrates suggests better conditions on the coast, which may be due to higher prey availability (Smith et al., 1981, Dawson \& Bortolotti, 2000, Zuberogoitia et al., 2013), better climatic conditions (Mearns \& Newton, 1988, Olsen \& Olsen, 1989, Dawson \& Bortolotti, 2000) or a higher prey capture rate along the coast, since peregrines hunt better in open areas, including the sea. Similarly, in the nearby province of Bizkaia, Zuberogoitia et al. (2002) detected a higher breeding output in those territories found along the coast, so breeding conditions along the Basque coast in the south-eastern Bay of Biscay seem to be very good for the Peregrine falcon within the region. However, these pairs breeding along the coast seem to be more sensitive to marine pollution events, such as the Prestige oil spill in 2002, that resulted in an increase of adult mortality rates and decreased fertility (Zuberogoitia et al., 2006).

With 35 pairs, representing 1.75 pairs $100 \mathrm{~km}^{2}$, Gipuzkoa has a relatively high breeding density compared with other zones in Spain, where the density was found to be $<1$ pair/100 km² (Zuberogoitia et al., 2002, Moral \& Molina, 2009). In provinces like Huesca, with abundant cliffs and high prey availability, the species can reach densities above 2.5 pairs/100 km² (Zuberogoitia et al., 2002, Moral \& Molina, 2009). In the Alps, Rizzolli et al. (2005) found a density of 1.16 pairs $/ 100 \mathrm{~km}^{2}$.

The Peregrine falcon is well distributed in Gipuzkoa, except in its central-western part, confirming the observations made in previous years (Álvarez et al., 2005). This is attributed to the lack of suitable breeding places, mainly cliffs (Olano, pers. obs.). Overall, the density and the relatively high productivity in Gipuzkoa suggest that this region offers good breeding opportunities for the species. Moreover, the fact that the population has remained stable during the last two decades may suggest that it has reached the carrying capacity of the region.

Natural cliffs situated either along the coast or inland, host most of the Peregrine falcon population in Gipuzkoa, in detriment of artificial structures such as quarries. This suggests that the natural habitat has a critical weight for the reproduction of this raptor in Gipuzkoa, so attention should be given to the protection of such cliffs from disturbances during breeding period. In Gipuzkoa, as in other nearby areas (Zuberogoitia et al., 2002), we have detected a seemingly increasing pressure on these habitats owing to open-air activities such as hiking or climbing, which cause breeding failure or lead to the abandonment of territories.

Whereas the use of quarries is a common phenomenon within Gipuzkoa (Álvarez et al., 2005) and the surrounding area (Azkona et al., 2000, Zuberogoitia et al., 2002), the use of buildings in Gipuzkoa represents a novelty. The single nest detected in one of the towers of the St. Sebastián cathedral represents the first urban nest site in the region, and would fit with the global tendency of Peregrines to breed in urban environments (Bird et al., 1996, Drewitt, 2014, Gahbauer et al., 2015). Even though 
breeding in cities can entail a number of hazards (e.g., collisions, especially in juvenile birds learning to fly around towers with reflective glass), urban areas often offer advantages such as abundant prey and nesting places as well as fewer predators, thus becoming a very attractive habitat for the species (Ratcliffe, 1993). Peregrines seem to select very tall, prominent buildings including cathedrals or skyscrapers (Bird et al., 1996), although at the same time the efforts carried out in many cities with nestboxes is known to attract peregrine falcons to many other types of buildings. The situation in Gipuzkoa, therefore, contrasts with cities like Madrid, with a population of seven urban pairs in 2017 (source: www.seo.org/halcon-peregrino-madrid). The peregrine falcon population in Madrid is 28 pairs (Moral \& Molina, 2009).

In conclusion, the peregrine falcon population in Gipuzkoa has remained constant during the last two decades (the decade from 2000 to 2010, and up to 2017), with one of the highest breeding densities in Spain. Breeding parameters are also high and, overall, the conservation status of the population is apparently good in Gipuzkoa.

\section{Acknowledgements}

The Peregrine falcon survey was funded by the Gipuzkoa Provincial Council. Thanks must be given to the support provided by I. Mendiola (Gipuzkoa Provincial Council). A. Urruzola collaborated on an occasional basis in the census. The Associated Editor (B. Martín), I. Zuberogoitia and one more reviewer provided very valuable comments that helped us to improve an earlier version of this work.

\section{Bibliography}

Álvarez, F., Olano, M., Aierbe, T., Vázquez, J., Izkeaga, P., Ugarte, J. 2005. Población, distribución y reproducción del Halcón peregrino (Falco peregrinus) en Gipuzkoa (20032004). Munibe, Cienc. nat. 56:113-132.

Arizaga, J., Laso, M. 2015. A quantification of illegal hunting of birds in Gipuzkoa (north of Spain). Eur. J. Wildlife Res. 61:795-799.

Azkona, P., Ceballos, O., Fernández, C. 2000. Censo de Halcones peregrinos (Falco peregrinus) nidificantes en Navarra (2000). Gobierno de Navarra, Inédito.

Bird, D.M., Varland, D.E., Negro, J. J. 1996. Raptors in human landscapes. Adaptation to built and cultivated environments. Academic Press, London.

BirdLife International. 2017. Species factsheet: Falco peregrinus.

Dawson, R.D., Bortolotti, G. R. 2000. Reproductive success of american kestrels: the role of prey abundante and weather. Condor 102:814-822. 
Devictor, V., Whittaker, R.J., Beltrame, C. 2010. Beyond scarcity: citizen science programmes as useful tools for conservation biogeography. Diversity and Distributions 16:354-362.

Dickinson, J.L., Shirk, J., Bonter, D., Bonney, R., Crain, R. L., Martin, J., Phillips, T., Purcell, K. 2012. The current state of citizen science as a tool for ecological research and public engagement. Frontiers in Ecology and the Environment 10:291-297.

Drewitt, E. 2014. Urban peregrines. Pelagic Monographs, Exeter.

Gahbauer, M.A., Bird, D.M., Clark, K.E., French, T., Brauning, D.W., McMorris, F. A. 2015. Productivity, mortality, and management of urban peregrine falcons in northeastern North America. J. Wildlife Manag. 79:10-19.

Jiguet, F., Devictor, V., Julliard, R., Couvet, D. 2012. French citizens monitoring ordinary birds provide tools for conservation and ecological sciences. Acta Oecologica 44:58-66.

Mearns, R., Newton, I. 1988. Factors affecting breeding success of Peregrines in South Scotland. J. An. Ecol. 57:903-916.

Moral, J.C., Molina, B. 2009. El halcón peregrino en España. Población reproductora en 2008 y método de censo. SEO/BirdLife, Madrid.

Newton, I. 1998. Population limitation in birds. Academic Press, London.

Olsen, P.D., Olsen, J. 1989. Breeding of the Peregrine Falcon Falco peregrinus: II Weather, nest quality and breeding success. Emu 89:6-14.

Pannekoek, J., Van Strien, A. 2005. TRIM 3 Manual. (TRends and Indices for Monitoring data). Research paper no. 0102, Statistics Netherlands, Voorburg.

QGIS Development Team. 2009. QGIS Geographic Information System. Open Source Geospatial Foundation. Available from http://qgis.osgeo.org.

R Core Team. 2014. R.: A language and environment for statistical computing. ISBN 3900051-07-0, Vienna, Austria.

Ratcliffe, D. A. 1993. The Peregrine Falcon. T \& AD Poyser, London.

Rizzolli, F., Sergio, F., Marchesi, L., Pedrini, P. 2005. Density, productivity, diet and population status of the Peregrine Falcon Falco peregrinus in the Italian Alps. Bird Study 52:188-192.

Smith, D.G., Murphy, J.R., Woffinden, N.D. 1981. Relationships between jackrabbit abundance and ferruginous hawk reproduction. The Condor 83:52-56.

Staneva, A., Burfield, I. 2017. European birds of conservation concern: populations, trends and national responsibilities. BirdLife International.

Steenhof, K., Newton, I. 2007. Assessing nesting success and productivity. Pages 181-191 in K. L. Bildstein, editor. Raptor research and management techniques. Hancock House, Blaine.

Tucker, G.M., Heath, M.F. 2004. Birds in Europe: population estimates, trends and conservation status. BirdLife International, Cambridge. 
White, C., Cade, T., Enderson, J. 2013. Peregrine Falcons of the World. Lynx Edicions, Bellaterra.

Wootton, J.T., Bell, D. A. 1992. A metapopulation model of the Peregrine Falcon in California: viability and management strategies. Ecological Applications 2:307-321.

Zuberogoitia, I., Enrique Martinez, J., Antonio Gonzalez-Oreja, J., Francisco Calvo, J., Zabala, J. 2013. The relationship between brood size and prey selection in a Peregrine Falcon population located in a strategic region on the Western European Flyway. J. Ornithol. 154:7382.

Zuberogoitia, I., Martínez, J. A., Azkona, A., Martínez, J. E., Castillo, I., Zabala, J. 2009. Using recruitment age, territorial fidelity and dispersal as decisive tools in the conservation and management of peregrine falcon (Falco peregrinus) populations: the case of a healthy population in Northern Spain. J. Ornithol. 150:95-101.

Zuberogoitia, I., Martínez, J. A., Iraeta, A., Azkona, A., Zabala, J., Jiménez, B., Merino, R., Gómez, G. 2006. Short-term effects of the prestige oil spill on the peregrine falcon (Falco peregrinus). Mar. Pollut. Bull. 52:1176-1181.

Zuberogoitia, I., Ruiz, F., Torres, J. J. 2002. El Halcón Peregrino. Diputación Foral de Bizkaia, Bilbao.

Fecha de recepción/Date of reception: 04/09/2017

Fecha de aceptación/Date of acceptance: 09-01-2018

Editor Asociado/Associate editor: Beatriz Martín 